\title{
Pengaruh Kompetensi, Motivasi Dan Komitmen Organisasi Terhadap Kinerja Karyawan PT. Thamrin Brothers A.Rivai Palembang
}

\author{
Ika Rakhmalina \\ Sekolah Tinggi Ilmu Ekonomi (STIE) Rahmaniyah Sekayu \\ Email: ika.rakhmalina1983@gmail.com
}

\begin{abstract}
This research entitled The Effect of Competence, Motivation and Organizational Commitment on Employee Performance of PT. Thamrin Brothers A. Rivai Palembang. The results of hypothesis testing through the $\mathrm{F}$ test (Simultaneous) using a confidence level of $90 \%$, show that there is a significant influence of competence, motivation and organizational commitment together on the performance of the employees of PT. Thamrin Brothers A. Rivai Palembang. Quantitative analysis model using multiple linear regression analysis tools. The results of hypothesis testing through the test (partial) show that there is a partially significant effect of competence on employee performance, there is a partially significant influence of motivation on employee performance and there is a partially significant effect of organizational commitment on the performance of employees of PT. Thamrin Brothers A. Rivai Palembang. The coefficient of determination test results prove that competence, motivation, and organizational commitment are able to contribute $91.0 \%$ in explaining changes that occur in employee performance. The researcher gave the first suggestion that PT. Thamrin Brothers A. Rivai Palembang, is expected to improve competence so that employees can optimally achieve a company goal including knowledge, understanding, abilities, values, attitudes, and interests. Second, leaders are expected to improve motivation to improve things including: work environment, fair and competitive wages, incentives and a sense of security at work. Third, leadership is expected to increase organizational commitment by including: justice and support, shared values, trust, organizational understanding, and employee involvement.
\end{abstract}

Keywords: Competence, Motivation, Organizational Commitment and Performance

\section{Pendahuluan}

Sumber daya manusia sangat penting bahkan tidak bisa dilepaskan dari sebuah organisasi, baik perusahaan ataupun institusi. Selain itu sumber daya manusia juga merupakan faktor yang mempengaruhi perkembangan perusahaan. Jadi bisa dikatakan sebuah perusahaan dapat berkembang dengan sangat besar apabila didalamnya memiliki banyak sumber daya manusia yang berkompeten dibidangnya, sebaliknya pula apabila sumber daya manusia bekerja disebuah perusahaan itu tidak berkualitas maka perkembangan perusahaan tersebut juga akan terhambat. Hasil kerja karyawan dalam menjalankan aktivitasnya ini disebut kinerja.

Kinerja merupakan pencapaian yang didapat oleh karyawan ataupun karyawan pada periode tertentu. Menurut Wibowo (2016) kinerja adalah tentang melakukan pekerjaan dan hasil yang dicapai dari pekerjaan tersebut. Kinerja adalah tentang apa yang dikerjakan dan bagaimana cara mengerjakan. Mencapai kinerja yang tinggi, senantiasa diperlukan karyawan yang mempunyai kemampuan serta keterampilan guna terwujudnya tenaga kerja yang produktif, sejahtera, dan berdaya saing nasional. 
Sedangkan arti atau definisi kinerja menurut Kasmir (2016) kinerja merupakan hasil kerja dan perilaku kerja karyawan dalam suatu periode tertentu biasanya 1 (satu) tahun.

Menurut Kasmir (2016) ada 13 faktor yang mempengaruhi kinerja yaitu, kemampuan dan keahlian, pengetahuan, rancangan kerja, kepribadian, motivasi kerja, kepemimpinan, gaya kepemimpinan, budaya organisasi, kepuasan kerja, lingkungan kerja, loyalitas, komitmen, dan disiplin kerja. Menurut Wibowo (2016) ada 7 indikator dalam kinerja karyawan, diantaranya yaitu : tujuan, standar, umpan balik, alat dan sarana, kompetensi, motif dan peluang.

Kompetensi adalah suatu kemampuan yang dimiliki oleh karyawan dengan berdasarkan dari kemampuan, pengetahuan dan juga pendidikan. Boyatzis (dalam Priansa, 2018) menyatakan bahwa kompetensi adalah kapasitas yang dimiliki karyawan, yang mengarah kepada perilaku yang sesuai dengan tuntutan pekerjaan serta sesuai dengan ketetapan organisasi, yang pada gilirannya akan membawa hasil seperti yang diinginkan. Kompetensi juga menunjukkan karakteristik pengetahuan dan keterampilan yang dimiliki atau dibutuhkan oleh setiap individu yang membuat mereka mampu untuk mengerjakan tugas dan tangggung jawab secra efektif dan meningkatka standar kualitas profesional dalam pekerjaaan. Dengan demikian, Kompetensi sangat penting di dalam suatu perusahaan untuk membantu menciptkan budaya kinerja yang tinggi.

Motivasi merupakan suatu rangsangan yang diberikan kepada karyawan atau karyawan, agar terciptanya keberhasilan dalam pencapaian kinerja karyawan. Motivasi menurut Sutrisno (2014) adalah faktor yang mendorong seseorang untuk melakukan suatu aktivitas tertentu, oleh karena itu motivasi seringkali diartikan pula sebagai faktor pendorong perilaku seseorang. Setiap aktivitas yang dilakukan oleh seseorang pasti memiliki suatu faktor yang mendorong aktivitas tersebut. Oleh karena itu, faktor pendorong seseorang untuk melakukan suatu aktivitas tertentu pada umumnya adalah kebutuhan keinginan orang tersebut.

Komitmen organisasi merupakan perasaan indetifikasi, pelibatan, dan loyalitas dinyatakan oleh pekerja terhadap perusahaan, organisasi atau unit dalam organisasi. Wibowo (2015). Komitmen organisasi pada setiap karyawan sangat penting karena dengan adanya komitmen maka karyawan dapat menjadi lebih bertanggung jawab, semangat kerja yang maksimal serta memiliki suatu kepercayaan pada nilai-nilai perusahaan terhadap pekerjaanya dibandingkan dengan karyawan yang tidak mempunyai komitmen bekerja.

PT. Thamrin Brothers A.Rivai Palembang terakhir mengalami permasalahan pada kinerja karyawan. Adapun indikator yang menyebabkan kinerja dari para karyawan menurun antara lain, insiatif dari para karyawan dalam menjalankan tugas yang diberikan oleh pimpinan masih belum dijalankan secara maksimal, serta tanggung jawab yang diberikan kepada karyawan masih terbilang belum memuaskan, disisi lain karyawan juga sering melakukan keterlambatan dalam absensi setiap bulannya. Hal ini terlihat dari tabel keterlambatan waktu kerja dari para karyawan sebagai berikut : 
Tabel 1. Persentase keterlambatan karyawan pada tahun 2019

\begin{tabular}{lll}
\hline Bulan & Persentase Keterlambatan & Persentase Kehadiran \\
\hline Januari & $7 \%$ & $94 \%$ \\
Febuari & $8 \%$ & $96 \%$ \\
Maret & $10 \%$ & $98 \%$ \\
April & $6 \%$ & $96 \%$ \\
Mei & $9 \%$ & $94 \%$ \\
Juni & $9 \%$ & $96 \%$ \\
Juli & $10 \%$ & $95 \%$ \\
Agustus & $9 \%$ & $80 \%$ \\
September & $8 \%$ & $96 \%$ \\
Oktober & $13 \%$ & $98 \%$ \\
November & $13 \%$ & $96 \%$ \\
Desember & $13 \%$ & $80 \%$ \\
\hline
\end{tabular}

Sumber : PT. Thamrin Brothers A.Rivai Palembang, 2020.

Kompetensi yang dimiliki oleh para karyawan juga mengalami permasalahan, hal ini terjadi karena kemampuan dari karyawan dalam menyelesaikan tugas yang berikan masih belum maksimal, adapun sikap yang dimiliki oleh karyawan juga dinilai kurang memiliki nilai tambah bagi tercapainya kinerja karyawan, disisi lain pengetahuan dari beberapa karyawan juga masih terbilang minim, dikarena ada beberapa karyawan yang memiliki latar belakang bukan dari dinas pendidikan atau instansi pemerintahan.

Motivasi yang dimiliki karyawan di PT. Thamrin Brothers A.Rivai Palembang masih terbilang rendah, dibuktikan dari lingkungan kerja yang dirasa oleh karyawan masih menjadi penyebab kurang nyamannya bagi para karyawan dalam bekerja, dikarenakan lingkungan yang jauh dari pusat kota, membuat karyawan cenderung merasa bosan. Insentif yang juga diketahui tidak ada diberikan kepada karyawan dalam bekerja melebihi jam kerja membuat karyawan tidak memiliki motivasi lebih dalam menjalanka tugas secara maksimal. Selain itu letak kantor dinas yang jauh dari pusat kota pun seringkali mengalami terjadinya tindak kejahatan seperti perampokan kendaraan bermotor, membuat karyawan merasa tidak adanya rasa aman dalam bekerja.

Dari sisi komitmen organisasi, PT. Thamrin Brothers A.Rivai Palembang terdapat beberapa permasalahan, seperti loyalitas dari karyawan yang dianggap masih terbilang rendah, kerjasama antar bidang yang masih belum tercipta dengan baik, hal ini berujung pada tingkat kepercayaan antar karyawan juga rendah. Berdasarkan uraian di atas, peneliti mengangkat penelitian ini dengan judul "Pengaruh Kompetensi, Motivasi dan Komitmen Organisasi Terhadap Kinerja Karyawan PT. Thamrin Brothers A.Rivai Palembang". Rumusan masalah yang akan di jawab pada tujuan penelitan, yaitu untuk 
menganalisis pertama pengaruh kompetensi, motivasi dan komitmen organisasi terhadap kinerja karyawan di PT. Thamrin Brothers A.Rivai Palembang. Kedua, pengaruh kompetensi terhadap kinerja karyawan. Ketiga, pengaruh motivasi terhadap kinerja karyawan. Keempat, pengaruh komitmen organisasi terhadap kinerja karyawan di PT. Thamrin Brothers A.Rivai Palembang.

\section{Tinjauan Literatur}

\subsection{Kinerja Karyawan}

\subsubsection{Pengertian Kinerja Karyawan}

Menurut Mangkunegara (2016) kinerja merupakan hasil dari suatu proses yang mengacu dan diukur selama periode waktu tertentu berdasarkan ketentuan atau kesepakatan yang telah ditetapkan sebelumnya. Menurut Wibowo (2014) kinerja adalah tentang melakukan pekerjaan dan hasil yang dicapai dari pekerjaan tersebut. Kinerja adalah tentang apa yang dikerjakan dan bagaimana cara mengerjakan. Mencapai kinerja yang tinggi, senantiasa diperlukan karyawan yang mempunyai kemampuan serta keterampilan guna terwujudnya tenaga kerja yang produktif, sejahtera, dan berdaya saing nasional. Sedangkan arti atau definisi kinerja menurut Kasmir (2016) kinerja merupakan hasil kerja dan perilaku kerja karyawan dalam suatu periode tertentu biasanya satu tahun.

\subsubsection{Faktor-faktor yang mempengaruhi kinerja karyawan}

Menurut Kasmir (2016) menguraikannya sebagai berikut:

\section{1). Kompetensi}

Kompetensi merupakan persyaratan utama dalam kinerja. Kompentensi merupakan kemampuan yang dimiliki oleh seseorang untuk menjalankan pekerjaan yang diberikan kepadanya dengan baik. Orang harus melakukan pekerjaan dengan baik. Kompetensi memungkinkan seseorang mewujudkan tugas yang berkaitan dengan pekerjaan yang diperlukan untuk mencapai tujuan.

\section{2). Kemampuan dan Keahlian}

Merupakan kemampuan atau skill yang dimiliki seseorang dalam melakukan suatu pekerjaan. Semakin memiliki kemampuan dan keahlian maka akan dapat menyelesaikan pekerjaannya secara benar, sesuai dengan yang telah ditetapkan. Artinya karyawan yang memiliki kemampuan dan keahlian yang lebih baik, maka akan memberikan kinerja yang baik pula demikian sebaliknya. Dengan demikian kemampuan dan keahlian akan mempengaruhi kinerja seseorang.

\section{3). Pengetahuan}

Maksudnya adalah pengetahuan tentang pekerjaan. Seseorang yang memiliki pengetahuan tentang pekerjaan secara baik akan memberikan hasil pekerjaan yang baik, demikian sebaliknya. Jadi dapat disimpulkan bahwa pengetahuan tentang pekerjaan akan mempengaruhi kinerja.

\section{4). Rancangan Kerja}

Merupakan rancangan pekerjaan yang akan memudahkan dalam mencapai tujuannya. Artinya jika suatu pekerjaan memiliki rancangan yang baik, maka akan memudahkan untuk menjalankan pekerjaan tersebut secara tepat dan benar. Demikian pula sebaliknya, maka dapat disimpulkan bahwa rancangan pekerjaan akan mempengaruhi kinerja seseorang. 
5). Kepribadian

Kepribadian seseorang atau karakter yang dimiliki seseorang. Setiap orang memiliki kepribadian atau karakter yang berbeda satu dengan yang lainnya. Seseorang yang memiliki kepribadian atau karakter yang baik akan dapat melakukan pekerjaan secara sungguh-sungguh penuh tanggung jawab sehingga hasil pekerjaan juga baik.

6). Motivasi Kerja

Motivasi kerja merupakan dorongan bagi seseorang untuk melakukan pekerjaan. Jika karyawan memiliki dorongan yang kuat dari dalam dirinya atau dorongan yang kuat dari luar dirinya (misalya dari pihak perusahaan), maka karyawan akan terangsang atau terdorong untuk melakukan pekerjaan dengan baik. Pada akhirnya dorongan atau rangsangan baik dari dalam maupun dari luar diri seseorang akan menghasilkan kinerja yang baik.

7). Kepemimpinan

Kepemimpinan merupakan perilaku seorang pemimpin dalam mengatur, mengelola dan memerintah bawahannya untuk mengerjakan suatu tugas dan tanggung jawab yang diberikannya.

8). Gaya Kepemimpinan

Merupakan gaya atau sikap seorang pemimpin dalam menghadapi atau memerintah bawahannya.

9). Budaya Organisasi

Merupakan kebiasaan-kebiasaan atau norma-norma yang berlaku dan dimiliki oleh suatu organisasi atau perusahaan. Kebiasaan-kebiasaan atau norma-norma ini mengatur hal-hal yang berlaku dan diterima secara umum serta harus dipatuhi oleh segenap anggota suatu perusahaan atau organisasi.

10). Kepuasan Kerja

Merupakan perasaan senang atau gembira, atau perasaan suka seseorang sebelum dan setelah melakukan suatu pekerjaan. Jika karyawan merasa senang atau gembira dengan kata lain menyukai pekerjaannya, maka hasil pekerjaan akan baik pula.

11). Lingkungan Kerja

Merupakan suasana atau kondisi disekitar lokasi tempat bekerja. Lingkungan kerja dapat berupa ruang, layout, sarana dan prasarana serta hubungan kerja dengan sesama rekan kerja.

12). Loyalitas

Merupakan kesetiaan karyawan untuk tetap bekerja dan membela perusahaan dimana tempatnya bekerja. Kesetiaan ini ditunjukan dengan terus bekerja sungguh-sungguh sekalipun perusahaannya dalam kondisi kurang baik.

13). Komitmen Organisasi

Merupakan kepatuhan karyawan untuk menjalankan kebijakan atau peraturan perusahaan dalam bekerja. Komitmen juga dapat diartikan kepatuhan karyawan kepada janji-janji yang telah dibuatnya. Atau dengan kata lain komitmen merupakan kepatuhan untuk menjalankan keputusan yang telah dibuat.

14). Disiplin Kerja

Merupakan usaha karyawan untuk menjalankan aktivitas kerjanya secara sungguh- 
sungguh. Disiplin kerja dalam hal ini dapat berupa waktu, misalnya masuk kerja selalu tepat waktu. Kemudian disiplin dalam mengerjakan apa yang diperintahkan kepadanya sesuai dengan perintah yang harus dikerjakan. Karyawan yang disiplin akan mempengaruhi kinerja.

2.1.3 Indikator Kinerja Karyawan.

Indikator kinerja karyawan menurut Mangkunegara (2016) adalah sebagai berikut:

1) Kualitas Kerja

Menunjukkan kerapian, ketelitian, keterkaitan hasil kerja dengan tidak tidak mengabaikan volume pekerjaan. Kualitas kerja yang baik dapat menghindari tingkat kesalahan dalam penyelesaian suatu pekerjaan yang dapat bermanfaat bagi kemajuan perusahaan.

2) Kuantitas Kerja

Menunjukkan banyaknya jumlah jenis pekerjaan yang dilakukan dalam satu waktu sehingga efisiensi dan efektivitas dapat terlaksana sesuai dengan tujuan perusahaan.

3) Tanggung Jawab

Menunjukkan seberapa besar karyawan dalam menerima dan melaksanakan pekerjaannya, mempertanggung jawabkan hasil kerja serta sarana dan prasarana yang digunakan dalam perilaku kerjanya setiap hari.

4) Kerjasama

Kesediaan karyawan untuk berpartisipasi dengan karyawan yang lain secara vertikal dan horizontal baik didalam maupun diluar pekerjaan sehingga hasil pekerjaan akan semakin baik.

5) Inisiatif

Inisiatif dari dalam diri anggota perusahaan untuk melakukan pekerjaan serta mengatasi masalah dalam pekerjaan tanpa menunggu perintah dari atasan atau menunjukkan tanggung jawab dalam pekerjaan yang sudah menjadi kewajiban seorang karyawan atau karyawan.

\subsection{Kompetensi}

\subsubsection{Pengertian Kompetensi}

Menurut Wibowo, (2016) kompetensi adalah suatu kemampuan untuk melakasanakan atau melakukan suatu pekerjaan atau tugas yang dilandasi atas keterampilan dan pengetahuan serta didukung oleh sikap kerja yang dituntut oleh pekerjaan tersebut. Sedangkan menurut Sutrisno, (2016) kompetensi sebagai suatu kemampuan yang dilandasi oleh keterampilan dan pengetahuan yang didukung oleh sikap kerja serta penerapannya dalam melaksanakan tugas dan pekerjaan di tempat kerja yang mengacu pada persyaratan kerja yang ditetapkan.

\subsubsection{Faktor-faktor yang mempengaruhi kompetensi.}

Mmenurut Zwell, (dalam Sutrisno, 2015) kompetensi seseorang dapat dipengaruhi oleh beberapa faktor antara lain:

1) Keyakinan dan nilai-nilai

Perilaku seseorang sangat dipengaruhi oleh keyakinannya terhadap dirinya sendiri dan orang lain. Bila orang percaya akan kemampuannya dalam melakukan sesuatu, 
maka hal tersebut akan bisa dikerjakan dengan lebih mudah.

2) Karakteristik kepribadian

Kepribadian bukanlah sesuatu yang tidak dapat dirubah, kepribadian seseorang akan mempengaruhi cara-cara orang tersebut dalam menyelesaikan permasalahan dalam kehidupan ini, dan hal ini akan membuat orang tersebut lebih kompeten. Seseorang akan berespons serta beradaftasi dengan lingkungan dan kekuatan sekitarnya, yang akan menambah kompetensi seseorang.

3) Motivasi

Motivasi adalah dorongan yang membuat seseorang mampu untuk melakukan sesuatu. Daya dorong yang lebih bersifat psikologis membuat bertambahnya kekuatan fisik, sehingga akan mempermudah dalam aktivitas kerja, yang menambah tingkat kompetensi seseorang. Dorongan atau motivasi yang diberikan atasan kepada bawahan juga berpengaruh baik terhadap kinerja staf.

4) Isu emosional

Kondisi emosional seseorang akan berpengaruh dalam setiap penampilannya, termasuk dalam penampilan kerjanya. Rasa percaya diri membuat orang akan dapat melakukan suatu pekerjaan dengan lebih baik, begitu juga sebaliknya, gangguan emosional seperti rasa takut dan malu juga bisa menurunkan performance/penampilan kerja seseorang, sehingga kompetensinya akan menurun.

5) Kemampuan intelektual

Kompetensi dipengaruhi oleh pemikiran intelektual, kognitif, analitis dan kemampuan konseptual. Tingkat intelektual dipengaruhi oleh pengalaman, proses pembelajaran yang sudah tentu pula kemampuan intelektual seseorang akan meningkatkan kompetensinya.

6) Budaya organisasi

Budaya organisasi berpengaruh pada kompetensi seseorang dalam berbagai kegiatan, karena budaya organisasi mempengaruhi kinerja, hubungan antar karyawan, motivasi kerja dan kesemuanya itu akan berpengaruh pada kompetensi orang tersebut.

\subsubsection{Indikator kompetensi}

Menurut Gordon, (dalam Sutrisno, 2017) menjelaskan beberapa aspek yang terkandung dalam konsep kompetensi sebagai berikut :

1) Pengetahuan

Kesadaran dalam bidang kognitif. Misalnya seseorang karyawan mengetahui cara melakukan identifikasi belajar, dan bagaiman melakukan pembelajaran yang baik sesuai dengan kebutuhan yang ada diperusahaan.

2) Pemahaman

Kedalaman kognitif, dan efektif yang dimiliki individu. Misalnya, seseorang karyawan dalam melaksanakan pembelajaran harus mempunyai pemahaman yang baik tentang karakteristik dan kondisi kerja secara efektif dan efisien.

3) Kemampuan

Sesuatu yang dimiliki oleh individu untuk melaksanakan tugas atau pekerjaan yang dibebankan kepadanya. Misalnya, kemampuan karyawan dalam memilih metode kerja yang dianggap efektif dan efisien. 


\section{4) Nilai}

Suatu standar perilaku yang telah diyakini dan secara psikologis telah menyatu dalam diri seseorang. Misalnya standar perilaku karyawan dalam melaksanakan tugas (kejujuran, keterbukaan ,demokratis, dan lain-lain)

5) Sikap

Sikap yaitu perasaan (senang-tidak senang, suka-tidak suka) atau reaksi terhadap suatu ransangan yang datang dari luar. Misalnya, reaksi terhadap krisis ekonomi, perasaan terhadap kenaikan gaji, dan sebagainya.

6) Minat

Kecenderungan seseorang untuk melakukan suatu perbuatan. Misalnya, melakukan suatu aktivitas kerja.

\subsection{Motivasi Kerja}

\subsubsection{Pengertian Motivasi}

Motivasi, tujuan organisasi dapat tercapai serta tercapai pula tujuan pribadi. Pemberian motivasi kepada seseorang merupakan suatu mata rantai yang berasal dari kebutuhan, menimbulkan keinginan, menimbulkan tindakan dan menghasilkan keputusan. Dari berbagai tahapan pemberian motivasi, faktor utama yaitu kebutuhan dan pengarahan perilaku. Pemberian motivasi haruslah diarahkan untuk mencapai tujuan organisasi, hanya dengan kejelasan tujuan, maka semua yang terlibat dalam organisasi dapat dengan mudah memahami dan melaksanakannya.

Motivasi menurut Sutrisno (2014) adalah suatu faktor yang mendorong seseorang untuk melakukan suatu aktivitas tertentu, oleh karena itu motivasi seringkali diartikan pula sebagai faktor pendorong perilaku seseorang. Setiap aktivitas yang dilakukan seseorang pasti memiliki suatu faktor yang mendorong aktivitas tersebut. Oleh karena itu, faktor pendorong dari seseorang untuk melakukan suatu aktivitas tertentu pada umumnya adalah kebutuhan serta keinginan orang tersebut.

Menurut Hasibuan (dalam Sutrisno, 2016) motivasi kerja merupakan suatu perangsang keinginan dan daya penggerak kemauan bekerja seseorang karena setiap motivasi merupakan tujuan tertentu yang ingin dicapai. Selain itu menurut Sondang P. Siagian (dalam Sutrisno, 2016) mengemukakan motivasi kerja adalah keadaan kejiwaan yang mendorong, mengaktifkan atau menggerakkan yang mengarahkan dan menyalurkan perilaku, sikap dan tindakan seseorang untuk mencapai tujuan.

Pemberian motivasi kerja kepada karyawan dapat dilakukan dengan pemenuhan kebutuhan sebagai dasar dalam melakukan kerja dan komunikasi persuasif, sehingga karyawan memiliki motivasi yang tinggi dan merasa puas terhadap pekerjaan yang dilakukan.

2.3.2 Jenis-jenis motivasi kerja

Menurut Hasibuan (2014) jenis motivasi adalah :

1) Motivasi Positif

Motivasi positif adalah proses untuk mencoba mempengaruhi orang lain agar menjalankan sesuatu yang kita inginkan dengan cara memberikan kemungkinan untuk mendapat hadiah. 
2) Motivasi negatif

Motivasi negatif adalah usaha untuk mempengaruhi seseorang agar mau melakukan sesuatu yang kita inginkan, tetapi teknik dasar yang digunakan adalah lewat kekuatan dan ketakutan.

Menurut Winardi (2016) motivasi kerja dibagi menjadi beberapa jenis dapat bersifat negatif dan positif, yakni :

1) Motivasi positif, yang kadang-kadang dinamakan "motivasi yang mengurangi perasaan cemas" (anxiety reducting motivation) atau "pendekatan wortel" (the carrot approach) dimana orang ditawari sesuatu yang bernilai (misalnya imbalan berupa uang, pujian dan kemungkinan untuk menjadi karyawan tetap) apabila kinerjanya memenuhi standar yang ditetapkan.

2) Motivasi negatif, yang sering kali dinamakan orang "pendekatan tongkat pemukul" (the stick approach) menggunakan ancaman hukuman (teguran-teguran, ancaman akan di PHK, ancaman akan diturunkan pangkat dan sebagainya) andaikata kinerja orang bersangkutan dibawah standar.

2.3.3 Tujuan Motivasi Kerja

Menurut Hasibuan (2014) tujuan motivasi adalah:

1) Meningkatkan moral dan kepuasan kerja karyawan.

2) Meningkatkan produktivitas kerja karyawan.

3) Mempertahankan kestabilan kerja karyawan.

4) Meningkatkan kedisiplinan kerja karyawan.

5) Meningkatkan kesejahteraan karyawan.

\subsubsection{Indikator-indikator Motivasi Kerja}

Menurut Sugiyono (2016) beberapa faktor yang mempengaruhi motivasi, yaitu :

1) Lingkungan Kerja

Segala sesuatu kondisi yang ada dan dirasakan oleh para karyawan atau karyawan yang bisa berpengaruh pada diri karyawan dalam melaksanakan tugas-tugas para karyawan.

2) Gaji yang adil dan kompetitif

Merupakan balas jasa dalam bentuk uang yang diterima karyawan sebagai konsekuensi dan statusnya sebagai karyawan yang memberikan kontribusi dalam pencapaian tujuan perusahaan.

3) Insentif

Pendorong atau perangsang yang diberikan dengan sengaja kepada pekerja agar semangat lebih besar untuk berprestasi

4) Rasa aman dalam bekerja

Rasa aman dalam bekerja merupakan hal yang membuat karyawan merasa dipelihara perusahaan, misalnya perusahaan memberikan asuransi kesehatan kepada karyawannya.

\subsection{Kinerja Komitmen Organisasi}

\subsubsection{Pengertian Komitmen Organisasi}

Menurut Ivancevich, Konopaske, dan Matteson (dalam Wibowo 2015) komitmen organisasi merupakan perasaan indentifikasi, pelibatan, dan loyalitas dinyatakan oleh pekerjaan terhadap perusahaan. Dengan demikian komitmen menyangkut tiga sifat. 
1) perasaan indetifikasi dengan tujuan organisasi

2) perasaan dari tugas organisasiperasaan loyalitas terhadap organisasi

3) komitmen organisasi sangat berpengaruh terhadap kinerja.

Menurut kreitner dan kinicki (dalam Wibowo 2015) komitmen adalah kesepakan untuk melakukan sesuatu untuk diri sendiri, individu lain, kelompok atau organisasi.

Sedangkan komitmen organisasi mencerminkan tingkatan keadaan dimana individu mengidentifikasi dirinya dengan organisasi dan terkait pada tujuannya.

Menurut Wibowo (2015) kinerja organisasi sangat ditentukan oleh kualitas sumber daya manusia, baik dilihat dari segi kompetensinya maupuan komitmenya. Keluarnya seorang pekerja berbakat akan memperburuk situasi. Apabila menghadapi keadaan negative, maka terdapat empat respon yang dilakuan karyawan yaitu,

1) Exit (keluar)

Apabila keadaan kerja negative, maka karyawan menggeser dari situasi tersebut lebih sering tidak hadir ditempat kerja atau secara sukarela meninggalakan pekerjaanya.

2) Voice ( mengeluarkan suara)

Berusaha mengubah situasi dengan menemukan anggota tim baru berusaha mengatasi situasi. Voice didefinisikan sebagai respon aktif, dimana individu berusaha memperbaiki situasi.

3) Loyally (loyalitas)

Disini, individu memelihara tingkat usaha terlepas dari ketidak senanganya. Loyalitas didefinisikan sebagai respon pasif, yang memelihara dukungan public atas situasi.

\subsubsection{Faktor-faktor yang Mempengaruhi Komitmen}

Menerut Mc Shance dan Von Gilow (dalam Wibowo 2015) memandang komitmen sebagai loyalitas organisasi. Cara untuk membangun komitmen organisasi adalah melalui:

\section{1) Keadilan Dan Dukungan (Justice And Support)}

Affective commitment lebih tinggi pada organisasi yang memenuhi kewajiban pada pekerjaan yang tinggi pada organisasi yang memenuhi kewajiban pada pekerja dan tinggi dengan nilai-nilai humanitarian seperti kejujuran, kehormatan, kemauan memanfaatkan dan intergeritas moral.

2) Nilai Besama (Shared Volues)

Affactive Commitment menunjukan indentitas orang pada organisasi, dan indetifikasi mencapai tingkat tertinggi ketika pekerja yakin nilai-nilai mereka sesuai dengan nilainilai dominan organisasi. Pengalaman pekerjaan lebih nyaman dan dapat diduga ketika mereka sepakat dengan nilai-nilai mendasari kepuasan korporasi.

3) Kepercayaan (trust)

Kepercayaan menunjukan harapan positif satu orang terhadap orang lain dalam situasi yang melibatkan resiko. Kepercayaan berati menetapkan nasip pada orang lain atau kelompok. Untuk menerima kepercayaan, maka kita juga harus menunjukan kepercayaan.Pekerja memperkenalkan dengan dan merasa berkewajiban bekerja untuk organisasi hanya apabila mereka mempercayai pemimpin mereka.

4) Pemahaman Organisasional (organizational comprehension)

Pemahaman organisasi menunjukan seberapa baik pekerja memahami organisasi, 
termasuk arah strategi, dinamikal sosial, dan tata fisik.Keperdulian ini merupakan syarat penting bagiaffactive comitment karena sulit untuk mengidentifikasi dengan suatu yang tidak kita ketahui dengan baik.

5) Pelibatan Pekerja (Employee Involvement)

Pelibatan pekerja meningkatkan affactive commitment dengan dengan memperkuat identitas socil pekerja dengan organisasi. Pekerja merasa mereka menjadi bagian dari otganisasi apabila mereka berpatisipasi dalam keputusan yang mengarah pada masa depan organisasi. Pelibatan pekerja juga membangun loyalitas karena memberi kekuasan ini menunjukan kepercayaan organisasi pada pekerja.

\subsubsection{Indikator komitmen organisasi}

Menurut Allen dan Mayer dalam Robbins (2012) mengemukakan yaitu :

1. Visi dan misi organisasi

2. Tujuan organisasi

3. Kepercayaan antar karyawan

4. Kerjasama antar bidang

5. Loyalitas

\subsection{Kerangka Pemikiran}

Kerangka berpikir penelitian ini menggunakan kajian deskriptif, dengan kata lain bahwa kajian yang peneliti terapkan menggunakan teori-teori yang dikemukakan para ahli. Hasil penelitian yang relevan dapat di dijelaskan secara paradigma alur pikir sebagai berikut :

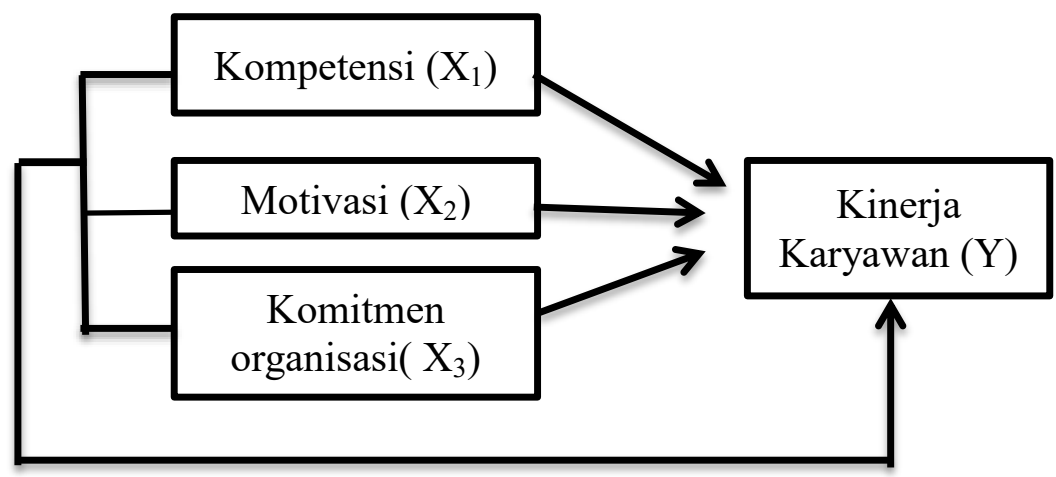

Gambar.1

Kerangka Pemikiran

\section{Metode Penelitian}

Pemilihan metode dalam suatu penelitian haruslah ditentukan dengan tepat agar dapat menghasilkan hasil penelitian yang lebih akurat. (Sugiyono 2016 :11) Jenis penelitian yang digunakan adalah penelitian Asosiatif (Fauzi, Dencik \& Asiati, 2019) karena penelitian ini bertujuan untuk mengetahui Pengaruh kompetensi, motivasi terhadap Kinerja Karyawan PT. Thamrin Brothers A.Rivai Palembang. Operasionalisasi variabel penelitian ini, seperti tabel berikut: 
Tabel. 2. Operasionalisasi Variabel

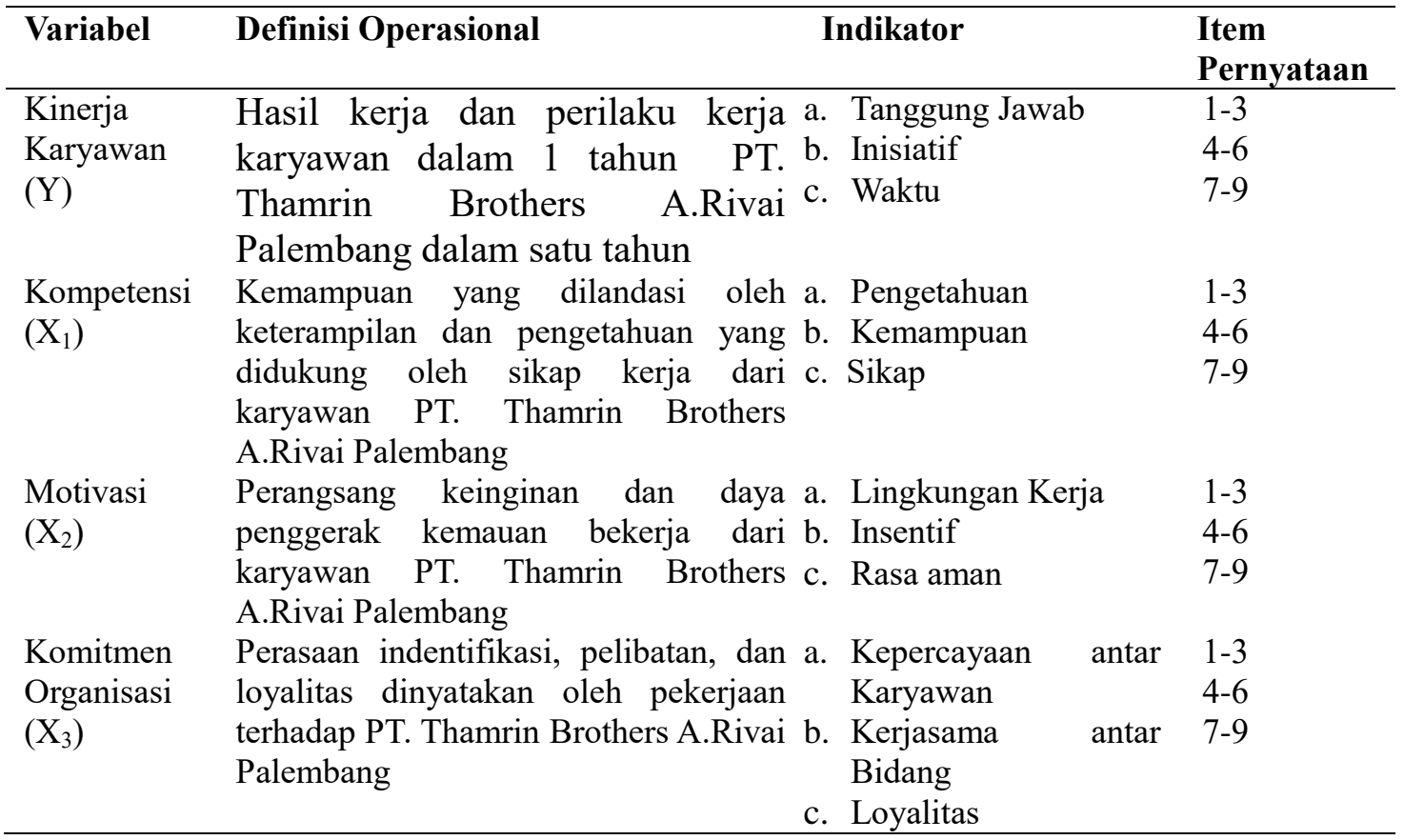

Sumber: Pemikiran Peneliti berdasarkan Teori Manajemen Sumberdaya Manusia, 2019.

Populasi adalah Karyawan PT. Thamrin Brothers A.Rivai Palembang yang berjumlah 31 karyawan. Berhubung populasi ini tidak terlalu banyak, maka penentuan sampel berdasarkan sensus, jadi populasi sama dengan sampel. Menurut Sugiyono (2016) sampel minimal berjumlah 30 responden.

Kuesioner merupakan teknik pengumpulan data yang dilakukan dengan cara memberi seperangkat pertanyaan/pernyataan tertulis kepada responden untuk dijawabnya (Sugiyono 2016). Menggunakan Skor Data Skala Likert jawaban, Sangat Setuju 5, Setuju 4, Netral 3, Tidak Setuju 2 dan Sangat Tidak Setuju 1.

Uji validitas dilakukan untuk mengukur ketepatan instrumen yang digunakan dalam suatu penelitian. Uji Validitas dapat dilakukan dengan menghitung korelasi antara skor masing-masing item pertanyaan dengan total skor. Kriteria yang digunakan dalam menentukan valid tidaknya pernyataan yang digunakan dalam penelitian ini adalah, tingkat signifikasi sebesar 0,05 , derajat kebebasan $(\mathrm{df})=\mathrm{n}-2=30-2=28$, didapat $\mathrm{r}$ tabel $=0,3610$. Uji Reliabelitas digunakan untuk melihat kekonsistenan dan stabilitas data atau temuan. Uji Reliabilitas yang digunakan dalam penelitian ini adalah metode internal. Metode internal dilakukan dengan melihat besarnya Croanbach Alpha ( $\mathrm{r}$ alpha) yang perhitungannya menggunakan prosedur Reliability Analisys pada pengaruh $\mathrm{X}_{1}, \mathrm{X}_{2}, \mathrm{X}_{3}$ terhadap Y. Menurut Latan Hengky (2012) dalam penelitian Confirmatory Research secara umum reliabilitas dapat diterima jika nilai Cronbach Alpha $>0,7$.

Analisis regresi linear berganda dalam penelitian ini digunakan untuk melakukan pengujian hipotesis.

Persamaan regresi berganda sebagai berikut :

$Y=a+b_{1} X_{1}+b_{2} X_{2}+b_{3} X_{3}+e$ 
Keterangan :

$\mathrm{Y} \quad=$ Kinerja Karyawan

$\mathrm{X}_{1} \quad=$ Kompetensi

$\mathrm{X}_{2}=$ Motivasi

$\mathrm{X}_{3}=$ Komitmen Organisasi

a $=$ Konstanta, besarnya nilai $\mathrm{Y} \mathrm{jika}_{1}, \mathrm{X}_{2}$ dan $\mathrm{X}_{3}$

$\mathrm{b}_{1}, \mathrm{~b}_{2}, \mathrm{~b}_{3}=$ koefisien regresi variabel $\mathrm{X}_{1} \mathrm{X}_{2}$ dan $\mathrm{X}_{3}$

e $\quad=$ Error $/$ Residual

\section{Hasil dan Pembahasan}

4.1. Hasil penelitian

4.1.1 Uji Validitas

Tabel 3. Uji Validitas

\begin{tabular}{|c|c|c|c|c|}
\hline Variabel & $\begin{array}{l}\text { Pernyataan } \\
\text { (Indikator) }\end{array}$ & $\mathrm{r}_{\text {hitung }}$ & $r_{\text {tabel }}(n-2)$ & Keterangan \\
\hline \multirow{9}{*}{$\begin{array}{c}\text { Kinerja Karyawan } \\
\text { (Y) }\end{array}$} & Y.P1 & 0.900 & 0,361 & Valid \\
\hline & Y.P2 & 0.934 & 0.361 & Valid \\
\hline & Y.P3 & 0.904 & 0.361 & Valid \\
\hline & Y.P4 & 0.877 & 0.361 & Valid \\
\hline & Y.P5 & 0.733 & 0.361 & Valid \\
\hline & Y.P6 & 0.859 & 0.361 & Valid \\
\hline & Y.P7 & 0.731 & 0.361 & Valid \\
\hline & Y.P8 & 0.861 & 0.361 & Valid \\
\hline & Y.P9 & 0.820 & 0.361 & Valid \\
\hline \multirow{9}{*}{ Kompetensi $\left(\mathrm{X}_{1}\right)$} & X1.P1 & 0.797 & 0.361 & Valid \\
\hline & $\mathrm{X} 1 . \mathrm{P} 2$ & 0.850 & 0.361 & Valid \\
\hline & X1.P3 & 0.924 & 0.361 & Valid \\
\hline & X1.P4 & 0.812 & 0.361 & Valid \\
\hline & X1.P5 & 0.809 & 0.361 & Valid \\
\hline & X1.P6 & 0.862 & 0.361 & Valid \\
\hline & X1.P7 & 0.818 & 0.361 & Valid \\
\hline & $\mathrm{X} 1 . \mathrm{P} 8$ & 0.956 & 0.361 & Valid \\
\hline & X1.P9 & 0.906 & 0.361 & Valid \\
\hline \multirow{9}{*}{ Motivasi $\left(\mathrm{X}_{2}\right)$} & X2.P1 & 0.860 & 0.361 & Valid \\
\hline & $\mathrm{X} 2 . \mathrm{P} 2$ & 0.949 & 0.361 & Valid \\
\hline & $\mathrm{X} 2 . \mathrm{P} 3$ & 0.822 & 0.361 & Valid \\
\hline & $\mathrm{X} 2 . \mathrm{P} 4$ & 0.885 & 0.361 & Valid \\
\hline & $\mathrm{X} 2 . \mathrm{P} 5$ & 0.804 & 0.361 & Valid \\
\hline & X2.P6 & 0.892 & 0.361 & Valid \\
\hline & X2.P7 & 0.949 & 0.361 & Valid \\
\hline & X2.P8 & 0.788 & 0.361 & Valid \\
\hline & X2.P9 & 0.858 & 0.361 & Valid \\
\hline \multirow{3}{*}{$\begin{array}{c}\text { Komitmen } \\
\text { Organisasi }\left(\mathrm{X}_{3}\right)\end{array}$} & X3.P1 & 0.848 & 0.361 & Valid \\
\hline & X3.P2 & 0.928 & 0.361 & Valid \\
\hline & X3.P3 & 0.872 & 0.361 & Valid \\
\hline
\end{tabular}




\begin{tabular}{lllll}
\hline & & & \\
X3.P4 & 0.748 & 0.361 & Valid \\
X3.P5 & 0.890 & 0.361 & Valid \\
X3.P6 & 0.900 & 0.361 & Valid \\
X3.P7 & 0.871 & 0.361 & Valid \\
X3.P8 & 0.703 & 0.361 & Valid \\
X3.P9 & 0.812 & 0.361 & Valid \\
\hline
\end{tabular}

Sumber : Berdasarkan olah data primer, 2019

Hasil uji validitas akan variabel Variabel Kinerja Karyawan (Y) dimana tidak terdapat item-item yang memiliki nilai corrected Item-Total Correlation $>0,3610$ (nilai $\mathrm{r}$ tabel dengan $\mathrm{N}=30$ ), sehingga semua item dalam variabel Kinerja Karyawan (Y), Kompetensi $\left(\mathrm{X}_{1}\right)$, Motivasi $\left(\mathrm{X}_{2}\right)$ dan Komitmen Organisasi $\left(\mathrm{X}_{3}\right)$, ini dapat dipergunakan.

\subsubsection{Uji Reliabilitas}

Uji reliabilitas dapat dilakukan secara bersama-sama terhadap seluruh butir pernyataan. Jika nilai Cronbach's Alpha $\geq 0,60$ maka dinyatakan reliabel. Jika nilai Cronbach's Alpha $<0,60$ maka dinyatakan tidak reliabel. Maka hasil dari pengujian reabilitas untuk setiap variabel, sebagai berikut :

Tabel 4. Uji Reliabilitas

\begin{tabular}{llll}
\hline Variabel & Cronbach's Alpha & $\begin{array}{l}\text { Standar } \\
\text { Reliabilitas }\end{array}$ & Keterangan \\
\hline Kinerja $(\mathrm{Y})$ & 0,950 & 0,60 & Reliabel \\
Kompetensi $\left(\mathrm{X}_{1}\right)$ & 0,954 & 0,60 & Reliabel \\
Motivasi $\left(\mathrm{X}_{2}\right)$ & 0,957 & 0,60 & Reliabel \\
Komitmen $\left(\mathrm{X}_{3}\right)$ & 0,949 & 0,60 & Reliabel \\
\hline Sumber : Berdasarkan olah data primer, 2019 & &
\end{tabular}

Berdasarkan uji reliabilitas pada Tabel di atas, keseluruhan indikator yang digunakan pada setiap butir pernyataan dalam penelitian ini dikatakan reliabel, karena tampak nilai Cronbach's Alpha 0,950 > 0,60 pada variabel kinerja, Cronbach's Alpha 0,954 > 0,60 pada variabel kompetensi, Cronbach's Alpha 0,957 > 0,60 pada variabel motivasi, dan Cronbach's Alpha 0,949 > 0,60 pada variabel komitmen organisasi, sehingga semua item pernyataan yang digunakan dinyatakan reliabel, dan indikator pada setiap pernyataan dapat digunakan sebagai alat ukur. 


\subsubsection{Analisis Data Penelitian}

1). Analisis Regresi Linier Berganda

Tabel 5. Analisis Regresi Linier Berganda

Coefficients $^{a}$

\begin{tabular}{|c|c|c|c|c|}
\hline \multirow{2}{*}{\multicolumn{2}{|c|}{ Model }} & \multicolumn{2}{|c|}{ Unstandardized Coefficients } & \multirow{2}{*}{$\begin{array}{c}\begin{array}{c}\text { Standardized } \\
\text { Coefficients }\end{array} \\
\text { Beta }\end{array}$} \\
\hline & & $\mathrm{B}$ & Std. Error & \\
\hline \multirow[t]{4}{*}{1} & (Constant) & 11.104 & 13.090 & \\
\hline & Kompetensi $\left(\mathrm{X}_{1}\right)$ & .105 & .161 & .098 \\
\hline & Motivasi $\left(\mathrm{X}_{2}\right)$ & 1.005 & .268 & 1.030 \\
\hline & Komitmen $\left(X_{3}\right)$ & .086 & .112 & .172 \\
\hline
\end{tabular}

a. Dependent Variable: $\mathrm{Y}$

Sumber : Hasil Output SPSS Versi 22, 2019

$$
Y=11,104+0,105 X_{1}+1,005 X_{2}+0,086 X_{3}
$$

a). Berdasarkan Tabel 5, menunjukkan bahwa nilai konstanta sebesar 11,104 (positif), menunjukkan variabel kompetensi, motivasi dan komitmen organisasi berpengaruh positif terhadap kinerja karyawan. Artinya apabila terjadi peningkatan pada kompetensi, motivasi dan komitmen organisasi maka kinerja karyawan akan meningkat, dan sebaliknya apabila kompetensi, motivasi dan komitmen organisasi menurun maka kinerja karyawan akan menjadi rendah menunjukkan variabel kompetensi, motivasi dan komitmen organisasi berpengaruh positif terhadap kinerja karyawan.

b). Nilai koefisien variabel kompetensi sebesar 0,105 (positif), menunjukkan variabel kompetensi berpengaruh positif terhadap kinerja karyawan. Artinya apabila terjadi peningkatan pada kompetensi maka kinerja karyawan akan meningkat, dan sebaliknya apabila kompetensi menurun maka kinerja karyawan akan menjadi rendah, dengan asumsi motivasi dan komitmen organisasi tetap.

c). Nilai koefisien variabel motivasi sebesar 1,005 (positif), menunjukkan variabel motivasi berpengaruh positif terhadap kinerja karyawan. Artinya apabila terjadi peningkatan pada motivasi maka kinerja karyawan akan meningkat, dan sebaliknya apabila motivasi menurun maka kinerja karyawan akan menjadi rendah, dengan asumsi kompetensi dan komitmen organisasi tetap.

d). Nilai koefisien variabel komitmen organisasi sebesar 0,086 (positif), menunjukkan variabel komitmen organisasi berpengaruh positif terhadap kinerja karyawan. Artinya apabila terjadi peningkatan pada komitmen organisasi maka kinerja karyawan akan meningkat, dan sebaliknya apabila komitmen organisasi menurun maka kinerja karyawan akan menjadi rendah, dengan asumsi kompetensi dan motivasi tetap.

Hasil analisis regresi linier berganda di atas, memperlihatkan bahwa variabel motivasi lebih berpengaruh secara dominan dalam mempengaruhi kinerja karyawan, sehingga dapat disimpulkan bahwa motivasi merupakan faktor utama yang mempengaruhi kinerja karyawan PT. Thamrin Brothers A.Rivai Palembang, sedangkan kompetensi dan komitmen organisasi merupakan faktor pendukung yang mempengaruhi kinerja karyawan. 
2). Uji Hipotesis

a). Uji F (Simultan

Uji $F$ (simultan) ini dimaksudkan untuk menguji variabel-variabel bebas secara simultan/bersama-sama terhadap variabel terikat, dengan hasil sebagai berikut :

Tabel 6. Uji F

\begin{tabular}{clccccc}
\hline \multirow{2}{*}{ Model } & & Sum of Squares & Df & Square & F & Sig. \\
\hline 1 & Regression & 138065.782 & $\mathbf{3}$ & 46021.927 & $\mathbf{4 1 9 . 8 0 9}$ & $\mathbf{0 . 0 0 0}$ \\
& Residual & 2959.896 & $\mathbf{2 7}$ & 109.626 & & \\
& Total & 141025.677 & 30 & & & \\
\hline
\end{tabular}

a. Dependent Variabel: Kinerja Karyawan

b. Predictors: (Constant), Kompetensi, Motivasi, Komitmen Organisasi

Sumber : Hasil Output SPSS Versi 22, 2019

Menentukan $\mathrm{F}_{\text {tabel }}$ dengan tingkat keyakinan $90 \%$ dan tingkat kesalahan $(\alpha) 10 \%=0,10$ dengan tingkat kebebasan (df) $\mathrm{v}_{1}=\mathrm{k}-1=3-1=2$, dan $\mathrm{v}_{2} \mathrm{n}-\mathrm{k}=30-3=27$ (df yang sama seperti pada Tabel 6. Jadi nilai $\mathrm{F}_{\text {tabel }}=2,73$

Berdasarkan Tabel 6 menunjukan bahwa nilai $F_{\text {hitung }}(419,809)>F_{\text {tabel }}(2,73)$, dengan tingkat sig.F $0,000<0,10$ (signifikan), maka Ho ditolak, artinya ada pengaruh signifikan kompetensi, motivasi dan komitmen organisasi secara bersama-sama terhadap kinerja Karyawan PT. Thamrin Brothers A.Rivai Palembang.

b). Uji t (Parsial)

Uji t ini dimaksudkan untuk menguji variabel-variabel bebas secara parsial/individual terhadap variabel terikat, dengan hasil sebagai berikut :

Tabel 7. Uji t

\begin{tabular}{|c|c|c|c|c|c|c|}
\hline \multicolumn{7}{|c|}{ Coefficients $^{a}$} \\
\hline \multirow{2}{*}{\multicolumn{2}{|c|}{ Model }} & \multicolumn{2}{|c|}{ Unstandardized Coefficients } & $\begin{array}{l}\text { Standardized } \\
\text { Coefficients }\end{array}$ & \multirow[b]{2}{*}{$\mathrm{T}$} & \multirow[b]{2}{*}{ Sig. } \\
\hline & & $\mathrm{B}$ & Std. Error & Beta & & \\
\hline \multirow[t]{4}{*}{1} & (Constant) & 11.104 & 13.090 & & .848 & .039 \\
\hline & Kompetensi $\left(\mathrm{X}_{1}\right)$ & .105 & .161 & .098 & 2.649 & .051 \\
\hline & Motivasi $\left(\mathrm{X}_{2}\right)$ & 1.005 & .268 & 1.030 & 3.747 & .000 \\
\hline & Komitmen $\left(\mathrm{X}_{3}\right)$ & .086 & .122 & .172 & 2.702 & .048 \\
\hline
\end{tabular}

a. Dependent Variable: $\mathrm{Y}$

Sumber : Hasil Output SPSS Versi 22, 2019

Menentukan $\mathrm{t}_{\text {tabel }}$ dengan tingkat keyakinan 90\% dan tingkat kesalahan $(\alpha) 10 \%=0,10$ dan tingkat kebebasan $(\mathrm{df})=\mathrm{n}-\mathrm{k}$. Maka $:(\mathrm{df})=0,10(31-3)$ adalah $0,10=29$. maka nilai $\mathrm{t}_{\text {tabel }}=1,669$

Berdasarkan Tabel 7 menunjukan Nilai $t_{\text {hitung }}$ untuk kompetensi sebesar 2,649 $>t_{\text {tabel }}$ 1,669, dengan tingkat sig.t $0,000<0,10$ (signifikan), maka Ho ditolak, artinya ada pengaruh signifikan kompetensi terhadap kinerja karyawan PT. Thamrin Brothers A.Rivai Palembang. 
Nilai $t_{\text {hitung }}$ untuk motivasi sebesar 3,747 $>\mathrm{t}_{\text {tabel }} 1,669$, dengan tingkat sig.t $0,000<0,10$ (signifikan), maka Ho ditolak, artinya ada pengaruh signifikan motivasi terhadap kinerja karyawan PT. Thamrin Brothers A.Rivai Palembang.

Nilai $t_{\text {hitung }}$ untuk komitmen organisasi sebesar 2,703 $>t_{\text {tabel }} 1,669$, dengan tingkat sig.t $0,000<0,10$ (signifikan), maka Ho ditolak, artinya ada pengaruh signifikan komitmen organisasi terhadap kinerja karyawan PT. Thamrin Brothers A.Rivai Palembang.

c). Uji Koefisien Determinasi $\left(\mathrm{R}^{2}\right)$

Uji koefisien determinasi ini digunakan untuk mengetahui seberapa besar sumbangan variabel bebas yaitu kompetensi, motivasi dan komitmen organisasi terhadap kinerja karyawan PT. Thamrin Brothers A.Rivai Palembang, dengan hasil sebagai berikut :

Tabel 8.Uji Koefisien Determinasi

\begin{tabular}{ccccc}
\hline Model & $\mathrm{R}$ & R Square & $\begin{array}{c}\text { Adjusted R } \\
\text { Square }\end{array}$ & $\begin{array}{c}\text { Std. Error of } \\
\text { the Estimate }\end{array}$ \\
\hline 1 & $0,956^{\mathrm{a}}$ & 0,914 & $\mathbf{0 , 9 1 0}$ & 15,494773 \\
\hline
\end{tabular}

Sumber : Berdasarkan Perhitungan SPSS Versi 22, 2021

Berdasarkan hasil perhitungan pada Tabel 8 di atas, diperoleh nilai Adjusted $R$ Square (koefisien determinasi) sebesar $0,910 \times 100 \%=91,0 \%$, artinya variabel kompetensi, motivasi dan komitmen organisasi mampu berkonstribusi terhadap naik turunnya kinerja karyawan, dengan besarnya sumbangan yang disebabkan sebesar 91,0\%. Sedangkan sisanya sebesar $9,0 \%$ dijelaskan oleh variabel-variabel lain yang tidak termasuk dalam penelitian ini.

\subsection{Pembahasan Hasil Penelitian}

\subsubsection{Pengaruh Kompetensi, Motivasi dan Komitmen Organisasi terhadap Kinerja Karyawan}

Berdasarkan hasil analisis regresi linier berganda, diketahui adanya pengaruh positif yang disebabkan variabel kompetensi, motivasi dan komitmen organisasi terhadap kinerja karyawan PT. Thamrin Brothers A.Rivai Palembang. Hasil uji hipotesis secara simultan dengan tingkat kepercayaan $90 \%$, menunjukan ada pengaruh yang signifikan kompetensi, motivasi dan komitmen organisasi terhadap kinerja karyawan PT. Thamrin Brothers A.Rivai Palembang. Artinya antara kompetensi, motivasi dan komitmen organisasi saling berkaitan dalam berkonstribusi mempengaruhi kinerja karyawan PT. Thamrin Brothers A.Rivai Palembang, hal ini juga dibuktikan melalui uji koefisien determinasi yang memperlihatkan sumbangan dari variabel kompetensi, motivasi dan komitmen organisasi sebesar 91,0\% konstribusinya terhadap kinerja karyawan.

Hasil penelitian tersebut membuktikan bahwa kompetensi, motivasi dan komitmen organisasi merupakan aspek yang sangat penting dalam mempengaruhi kinerja karyawan. Sebagaimana tinjauan terhadap rendahnya kinerja karyawan PT. Thamrin Brothers A.Rivai Palembang, yang disebabkan rendahnya faktor kompetensi, motivasi dan komitmen organisasi. Sebab apabila dihubungkan dengan gambaran umum jawaban responden pada kuesioner variabel kompetensi, motivasi dan komitmen organisasi yang telah ditunjukkan, yang memperlihatkan jawaban ketidak setujuan yang cukup tinggi atas kuesioner tipe positif, maka hal ini membuktikan banyak karyawan yang mengakui 
kurangnya kompetensi, motivasi dan komitmen organisasi di PT. Thamrin Brothers A.Rivai Palembang. Sehingga dampaknya kinerja karyawan PT. Thamrin Brothers A.Rivai Palembang juga mengalami penurunan, sebagaimana kekonsistenan hubungannya dengan hasil jawaban responden pada variabel kinerja karyawan yang menunjukkan tingkat yang rendah. Maka hasil jawaban responden tersebut memperlihatkan hubungan sebab akibat yang saling mempengaruhi dan saling timbal balik, yang mengartikan bahwa dampak kompetensi, motivasi dan komitmen organisasi akan berdampak menurunkan kinerja karyawan, dan sebaliknya apabila kompetensi, motivasi dan komitmen organisasi dapat ditingkatkan oleh PT. Thamrin Brothers A.Rivai Palembang, maka akan berdampak meningkatkan kinerja karyawan.

Hasil ini sejalan dengan teori yang dinyatakan oleh Kasmir (2016), mengenai faktorfaktor yang mempengaruhi kinerja karyawan ialah: (1) kompetensi, (2) pengetahuan, (3) rancangan kerja, (4) kepribadian, (5) motivasi kerja, (6) kepemimpinan, (7) gaya kepemimpinan, (8) budaya organisasi, (9) kepuasan kerja, (10) lingkungan kerja, (11) loyalitas, (12) komitmen organisasi, (13) stress kerja dan (14) disiplin kerja. Berdasarkan faktor-faktor tersebut memperkuat hasil dari penelitian ini, sebab dalam teori tersebut dapat dilihat bahwa kompetensi, motivasi dan komitmen organisasi termasuk ke dalam faktor-faktor yang mempengaruhi kinerja karyawan.

Hasil ini didukung pula oleh penelitian yang dilakukan oleh Hani Humaeriyah (2010), dengan judul "Pengaruh Kompetensi, Komitmen Organisasi dan Motivasi Kerja Terhadap Kinerja Karyawan di Kantor Pos Bandung 40000". Hasil penelitiannya menunjukkan bahwa ada pengaruh positif dan signifikan kompetensi, motivasi dan komitmen organisasi secara bersama-sama terhadap kinerja karyawan. Maka hasil penelitian tersebut sejalan dengan penelitian ini, dengan hasil yang sama-sama menunjukkan ada pengaruh kompetensi, motivasi dan komitmen organisasi secara bersama-sama terhadap kinerja karyawan.

Penelitian yang dilakukan oleh Hatijah, Masdar Mas'ud dan Nurpadilla (2019), dengan judul "Pengaruh Kompetensi, Motivasi dan Komitmen Organisasi Terhadap Kinerja Karyawan di Dinas Pekerjaan Umum Kabupaten Enrekang". Hasil penelitiannya juga menunjukkan bahwa ada pengaruh positif dan signifikan kompetensi, motivasi dan komitmen organisasi secara bersama-sama terhadap kinerja karyawan. Maka hasil penelitian tersebut juga sejalan dengan penelitian ini, dengan hasil yang sama-sama menunjukkan ada pengaruh kompetensi, motivasi dan komitmen organisasi secara bersama-sama terhadap kinerja karyawan. Penelitian yang dilakukan oleh Dwy Prasetyo (2011), dengan judul "Pengaruh Motivasi Kerja, Kompetensi dan Komitmen Organisasi Terhadap Kinerja Karyawan PT. Jiwasraya Persero Surabaya”. Hasil penelitiannya juga menunjukkan bahwa ada pengaruh positif dan signifikan motivasi kerja, kompetensi dan komitmen organisasi secara bersama-sama terhadap kinerja karyawan. Maka hasil penelitian tersebut juga sejalan dengan penelitian ini, dengan hasil yang sama-sama menunjukkan ada pengaruh kompetensi, motivasi dan komitmen organisasi secara bersama-sama terhadap kinerja karyawan.

\subsubsection{Pengaruh Kompetensi Kerja terhadap Kinerja Karyawan}

Berdasarkan hasil pengujian hipotesis secara parsial yang telah dilakukan, diketahui ada pengaruh positif dan signifikan kompetensi terhadap kinerja karyawan PT. Thamrin Brothers A.Rivai Palembang. Hasil ini menandakan bahwa apabila kompetensi dapat 
ditingkatkan maka akan berdampak positif meningkatkan kinerja karyawan. Hasil ini sejalan dengan teori yang dinyatakan oleh Kasmir (2016), mengenai faktor-faktor yang mempengaruhi kinerja karyawan ialah: (1) kompetensi, (2) pengetahuan, (3) rancangan kerja, (4) kepribadian, (5) motivasi kerja, (6) kepemimpinan, (7) gaya kepemimpinan, (8) budaya organisasi, (9) kepuasan kerja, (10) lingkungan kerja, (11) loyalitas, (12) komitmen, dan (13) disiplin kerja. Hasil ini didukung penelitian yang dilakukan oleh Hani Humaeriyah (2010), Hatijah, Masdar Mas'ud dan Nurpadilla (2019), Dwy Prasetyo (2011) dengan hasil yang serupa, menyatakan ada pengaruh kompetensi secara parsial terhadap kinerja karyawan.

Pengaruh kompetensi terhadap kinerja karyawan, membuktikan bahwa kompetensi memiliki konstribusi besar dalam membangun kinerja karyawan, karena peran seorang karyawan harus memiliki kompetensi dalam melaksanakan tugas yang diberikan, sehingga tugas yang diberikan dapat dilaksanakan dengan secara maksimal oleh para karyawan, dengan begitu didalam pelayanan pun menjadi optimal. Sehubungan dengan rendahnya kompetensi yang dimiliki oleh karyawan PT. Thamrin Brothers A.Rivai Palembang, maka hal ini berdampak pada penurunan kinerja karyawannya, terkait tingkat kompetensi yang dimiliki karyawan, ketidak sanggupan karyawan dalam menjalankan pekerjaan yang diberikan oleh perusahaan.

Berdasarkan permasalahan yang terjadi di PT. Thamrin Brothers A.Rivai Palembang, maka perusahaan hendaknya meningkatkan kompetensi karyawannya, diantaranya dalam hal pengetahuan, pemahaman, kemampuan, nilai, sikap dan minat. Sehingga apabila aspek-aspek yang bermasalah ini dapat diatasi dengan baik, maka akan menciptakan suatu kondisi kerja yang lebih terkoordinir dengan baik, dengan demikian karyawan akan menjadi lebih baik dari pada sebelumnya, sehingga karyawan akan menghasilkan kinerja yang baik.

\subsubsection{Pengaruh Motivasi terhadap Kinerja Karyawan}

Berdasarkan hasil pengujian hipotesis secara parsial yang telah dilakukan, diketahui ada pengaruh positif dan signifikan motivasi terhadap kinerja karyawan PT. Thamrin Brothers A.Rivai Palembang. Hasil ini menandakan bahwa apabila motivasi dapat ditingkatkan maka akan berdampak positif meningkatkan kinerja karyawan. Hasil ini sejalan dengan teori yang dinyatakan oleh Kasmir (2016), mengenai faktor-faktor yang mempengaruhi kinerja karyawan ialah: (1) kompetensi, (2) pengetahuan, (3) rancangan kerja, (4) kepribadian, (5) motivasi kerja, (6) kepemimpinan, (7) gaya kepemimpinan, (8) budaya organisasi, (9) kepuasan kerja, (10) lingkungan kerja, (11) loyalitas, (12) komitmen, (13) stres kerja dan (14) disiplin kerja.

Hasil ini didukung penelitian yang dilakukan oleh Hani Humaeriyah (2010), Hatijah, Masdar Mas'ud dan Nurpadilla (2019), Dwy Prasetyo (2011) dengan hasil yang serupa, menyatakan ada pengaruh kompetensi secara parsial terhadap kinerja karyawan.

Pengaruh motivasi terhadap kinerja karyawan, memberikan suatu gambaran bahwa motivasi memiliki konstribusi dalam meningkatkan kinerja karyawan, sebab motivasi sebagai suatu bentuk bukti tinggi rendahnya rangsangan terhadap cara bagaimana karyawan dapat melalukan tugasnya dengan baik dan secara maksimal. 


\subsubsection{Pengaruh Kompetensi Terhadap Kinerja Karyawan}

Berdasarkan hasil pengujian hipotesis secara parsial yang telah dilakukan, diketahui ada pengaruh positif dan signifikan antara kompetensi terhadap kinerja karyawan PT. Thamrin Brothers A.Rivai Palembang. Hasil ini menandakan bahwa apabila kompetensi dapat ditingkatkan maka akan berdampak positif meningkatkan kinerja karyawan. Hasil ini sejalan dengan teori yang dinyatakan oleh Kasmir (2016), mengenai faktor-faktor yang mempengaruhi kinerja karyawan ialah: (1) kompetensi, (2) pengetahuan, (3) rancangan kerja, (4) kepribadian, (5) motivasi kerja, (6) kepemimpinan, (7) gaya kepemimpinan, (8) budaya organisasi, (9) kepuasan kerja, (10) lingkungan kerja, (11) loyalitas, (12) komitmen, dan (13) disiplin kerja.

Hasil ini didukung penelitian yang dilakukan oleh Hani Humaeriyah (2010), Hatijah, Masdar Mas'ud dan Nurpadilla (2019), Dwy Prasetyo (2011) dengan hasil yang serupa, menyatakan ada pengaruh kompetensi secara parsial terhadap kinerja karyawan.

Pengaruh komitmen organisasi terhadap kinerja karyawan, memberikan suatu gambaran bahwa komitmen organisasi memiliki konstribusi dalam meningkatkan kinerja karyawan, karena komitmen organisasi merupakan suatu faktor yang sifatnya untuk memastikan bahwa tujuan yang akan dicapai oleh karyawan dapat tercapai, sebab kepuasan kerja sebagai salah satu bentuk kuat atau tidak suatu perusahaan atau organisasi yang dinaungi.

\section{Kesimpulan}

Berdasarkan hasil penelitian dan pembahasan, maka dapat disimpulkan, pertama terdapat pengaruh signifikan kompetensi, motivasi dan komitmen organisasi secara bersama-sama terhadap kinerja karyawan PT. Thamrin Brothers A.Rivai Palembang. Kedua, terdapat pengaruh signifikan kompetensi secara parsial terhadap kinerja karyawan, ada pengaruh signifikan motivasi secara parsial terhadap kinerja karyawan dan ada pengaruh signifikan komitmen organisasi secara parsial terhadap kinerja karyawan PT. Thamrin Brothers A.Rivai Palembang. Ketiga, Hasil uji koefisien determinasi membuktikan bahwa kompetensi, motivasi, dan komitmen organisasi mampu berkonstribusi sebesar $91,0 \%$ dalam menjelaskan perubahan yang terjadi terhadap kinerja karyawan.

Peneliti memberikan beberapa saran, pertama, PT. Thamrin Brothers A.Rivai Palembang, diharapkan meningkatkan kompetensi agar karyawan dapat secara maksimal mencapai suatu tujuan perusahaan meliputi pengetahuan, pemahaman, kemampuan, nilai, sikap, dan minat. Kedua, Pimpinan diharapkan memperbaiki motivasi memperbaiki hal-hal meliputi : lingkungan kerja, gaji yang adil dan kompetitif, insentif dan rasa aman dalam bekerja. Ketiga, Pimpinan diharapkan dapat meningkatkan komitmen organisasi dengan meliputi : keadilan dan dukungan, nilai bersama, kepercayaan, pemahaman organisasional, dan pelibatan pekerja.

\section{Referensi}

Fauzi, F., Dencik, A. B., \& Asiati, D. I. (2019). Metodologi Penelitian untuk manajemen dan akuntansi. Jakarta: Salemba Empat.

Hasibuan, M.S.P. (2014). Manajemen SDM. Jakarta : PT.Bumi Aksara. 
Kasmir. (2016). Manajemen SDM (Teori dan Praktik). Jakarta : PT. Raja Grafindo Persada.

Mangkunegara, A.A.A.P. (2016). Manajemen SDM Perusahaan. Bandung : PT.Remaja Rosdakarya

Sondang, P.S.(2016). Manajemen SDM. Jakarta : PT.Bumi Aksara.

Sugiyono. (2016). Metode Penelitian Kuantitatif, Kualitatif dan $R \& D$. Bandung : Alfabeta.

Sutrisno, E. (2014). Manajemen SDM. Cetak keenam. Jakarta : Pranada Media Group.

Wibowo. (2016). Manajemen Kinerja. Edisi kelima, Penerbit PT. Raja Grafindo Persada, Jakarta.

\section{Copyrights}

Copyright for this article is retained by the author(s), with first publication rights granted to the journal.

This is an open-access article distributed under the terms and conditions of the Creative Commons Attribution license (http://creativecommons.org/licenses/by/4.0/) 